\title{
Foliar applications of phosphorus, calcium, boron and potassium and their impacts on the seed yield and physiological and nutritional qualities of soybean
}

\author{
Cleyton da Silva Domingos ${ }^{1}$, Michel Esper Neto ${ }^{2 *}$, Marcos Renan Besen ${ }^{1}$, Éder Júnior de Oliveira Zampar ${ }^{1}$, \\ Marcelo Augusto Batista ${ }^{1}$, Carlos Alberto Scapim¹, Tadeu Takeyoshi Inoue ${ }^{1}$, Alessandro Lucca Braccini ${ }^{1}$
}

${ }^{1}$ Maringá State University - Colombo Avenue, 5790, Zona 7, Maringá, Paraná State, ${ }^{2}$ Fortgreen Comercial Agrícola - Curitiba Street, 805 , Parque Industrial, Paiçandu, Paraná State, Brazil.

\section{A B S T R A C T}

\begin{abstract}
Using seeds of high physiological quality is important the establishment of a crop. Practices for quality seed production include sowing in the offseason and applying foliar macro and micronutrients to supplement fertilizers applied to the soil. The aim of this research was to evaluate the soybean yield and the physiological quality and nutritional content of seeds. Foliar fertilizer $(24 \% \mathrm{P}, 8 \% \mathrm{Ca}, 4 \%$ $\mathrm{K}$ and $2.5 \% \mathrm{~B}$ ) was applied at $0.50,1.0,1.5,2.0$ and $2.5 \mathrm{~kg} \mathrm{ha}^{-1}$ at the $\mathrm{R} 3$ soybean stage in a completely randomized design with six replications. The experiment was carried out at two sites. The following traits were evaluated at the R6 stage: the final stand, plant height, height of the first pod insertion, number of branches and number of pods per plant. After the soybeans were harvested, the thousand grain mass and yield were evaluated. The contents of nitrogen, phosphorus, potassium, calcium, magnesium, sulfur, zinc, iron, copper and boron were evaluated. Furthermore, the germination, first germination count, accelerated aging, modified cold, electric conductivity and emergency speed index were measured. The data were analyzed by means of joint analysis. When the foliar fertilizer rates were significant, the polynomial regression models were adjusted. The number of pods per plant and yield increased at site 1 (Rancho Alegre d 'Oeste). Application of the foliar fertilizer only influenced the emergency speed index at site 2 (Mariluz) with regard to the physiological quality of the seeds. The P content was positively affected at both sites; the K, S, Zn and B contents were only positively affected at site 2 .
\end{abstract}

Keywords: Foliar fertilizer, Plant nutrients, Seed quality

\section{INTRODUCTION}

Soybean is the most important legume in theBrazilian economy and also worldwide, accounting for more than $45 \%$ of all grain production in Brazil (Conab, 2014). This crop also has the same impact relative to seed production, which corresponds to $33 \%$ of all seeds marketed and produced in Brazil.

According to Peretti (1994), the seed is the most important input in the production chain and its physiological quality is fundamental for the success of the crop. The physiological quality of seeds is influenced by the production and storage conditions. Larger losses in this quality are expected under conditions of high humidity and temperatures (Marcos Filho, 2005). To obtain seeds with higher quality than those obtained in the summer harvest, some farmers have adopted later times for soybean cultivation, with a sowing date between December and January because, at harvest, the rainfall and temperature have already decreased.

Along with this management practice, nutrients are provided via foliar application to complement the nutrients applied to the soil. This type of fertilization is not a recent technique and has been used for more than one hundred years (SBCS/NEPAR, 2019). Among the nutrients applied in this way, the most commonly studied are calcium (Ca) and boron (B), and normally, applications of these nutrients are made during the preflowering, flowering or postflowering stage (Burton et al., 2000; Bevilaqua et al., 2002; Souza et al., 2008; Macedo et al., 2002; Arantes et al., 2009; Seidel and Basso, 2012 and Esper Neto et al., 2018). 
Another nutrient of great importance, whose presence in the soil has been well defined, is phosphorus $(\mathrm{P})$, although gaps exist inan understanding of its importance via foliar application,with few references existing in the literature. According to Rosolem (1982), soybean shows the greatest need for P between the V4 and R6 stages, an event that was also reported by Zobiole et al. (2012), who researched nutrient uptake by soybean and found the inflection point of higher absorption in $\mathrm{P}$ to occur after 80 days of the development cycle, corresponding to the phenological stage R5. According to Rosolem and Boaretto (1987), although the highest absorption rate is during flowering and the beginning of grain filling, greater amounts may be absorbed after the flowering stages.

Some authors have found that the application of foliar $\mathrm{P}$ to soybean increases the concentration of the element in the seed produced (Vieira et al., 1987; Trigo et al.,1997; Corrêa et al., 2004; Peske et al., 2009; Marin, 2012) and that this positively affects the physiological seed quality. Nevertheless, research has not shown the joint application of $\mathrm{P}, \mathrm{Ca}, \mathrm{K}$ and $\mathrm{B}$ in the same product but, instead, has shown only $\mathrm{Ca}$ and $\mathrm{B}$ together or $\mathrm{P}$ and $\mathrm{B}$ in isolation. Rezende et al. (2005), after performing research with foliar application of $\mathrm{P}$ (2 $\mathrm{L} \mathrm{ha}^{-1}$ of a product with $30 \% \mathrm{P}$ ), observed a significant increase in soybean yield (357 kg $\mathrm{ha}^{-1}$ ) when the element was applied at the V5 stage. Other evaluated traits, such as the nutrient content in the leaves, lodging, height of plants, and insertion of the first pod did not present significant differences (Rezende et al., 2005).

$\mathrm{K}$ foliar application in postemergence has shown some potential advantages, with farmers being able to mitigate observed $\mathrm{K}$ deficiency due to low content in the soil, management practices or climatic conditions. Nevertheless, when the area has been sprayed with glyphosate, the foliar application of nutrients may be more economical (Nelson et al., 2005).

Therefore, the hypothesis of this research is that foliar supplemental fertilization with $\mathrm{P}, \mathrm{Ca}, \mathrm{K}$ and $\mathrm{B}$ at appropriate rates and times increases the physiological quality of the seeds produced in the soybean crop. Thus, the aim was to evaluate the agronomic yield, physiological quality and nutritional contents of soybean seeds produced after the application of these elements in two locations in western Paraná State, Brazil.

\section{MATERIAL AND METHODS}

\section{Experimental area characterization}

The experiments were carried out in 2014 at two sites located in the western region of Paraná State, Brazil. One site is at a latitude of $24^{\circ} 07.52^{\prime} \mathrm{S}$ and $53^{\circ} 13.85^{\prime} \mathrm{W}$ (Mariluz), with an average altitude of $367 \mathrm{~m}$, and the other site is at a latitude of $24^{\circ} 22.212^{\prime} \mathrm{S}$ and longitude of $53^{\circ} 01.636^{\prime} \mathrm{W}$ (Rancho Alegre d'Oeste), with an average altitude of $385 \mathrm{~m}$. The climate at both sites is classified as Cfa (Alvarez et al., 2013).

Soil from both experimental areas was classified as a clayey eutrophic Red Latosol (Embrapa, 2013). Soil chemical analyses of both areas were conducted for characterization. The results of the analyses are shown in Table 1.and Fig.1 shows climatic data during the experimental time.

\section{Experimental design and treatments}

The experimental design was completely randomized blocks, with six rates of foliar fertilizer application $(24 \% \mathrm{P}$,

Table 1: Analysis of soil fertility characterization in the 0-0.2 m layer in Mariluz and Rancho Alegre d'Oeste

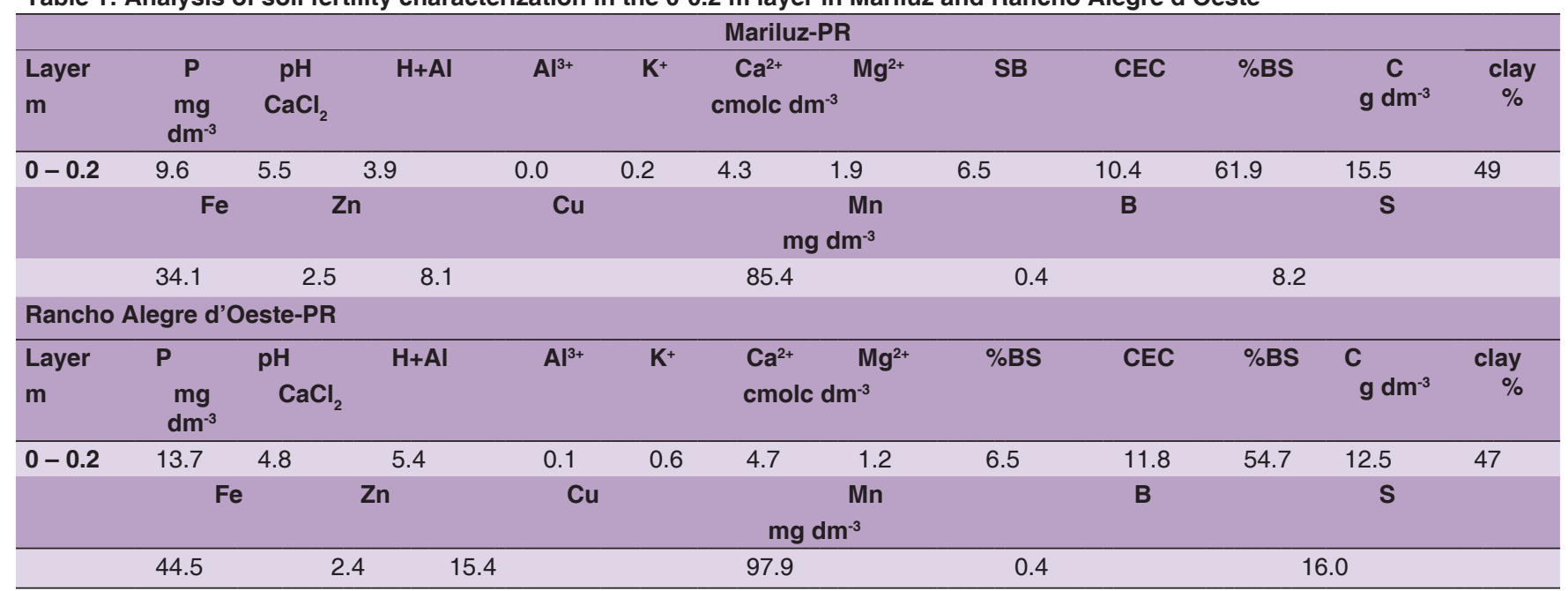

$\mathrm{pH}_{\mathrm{CaCl}}$ (1:2.5); $\mathrm{H}+\mathrm{Al}$ determined indirectly by $\mathrm{pH}$ SMP (Shoemaker, McLean, Pratt) buffer method; $\mathrm{Al}, \mathrm{Ca}$ and $\mathrm{Mg}$ extracted by $\mathrm{KCl} 1$ mol L-1; $\mathrm{P}, \mathrm{K}, \mathrm{Fe}$, $\mathrm{Cu}, \mathrm{Mn}$ and $\mathrm{Zn}$ extracted by Mehlich 1 ; $\mathrm{B}$ extracted by hot water; $\mathrm{S}$ extracted by $\left[\mathrm{Ca}\left(\mathrm{H}_{2} \mathrm{PO}_{4}\right)_{2}\right]$; Sum of bases $(\mathrm{SB}=\mathrm{Ca}+\mathrm{Mg}+\mathrm{K})$; Cation exchange capacity $(\mathrm{CEC}=\mathrm{SB}+\mathrm{H}+\mathrm{Al}) ; \mathrm{C}$ determined by Walkey Black 


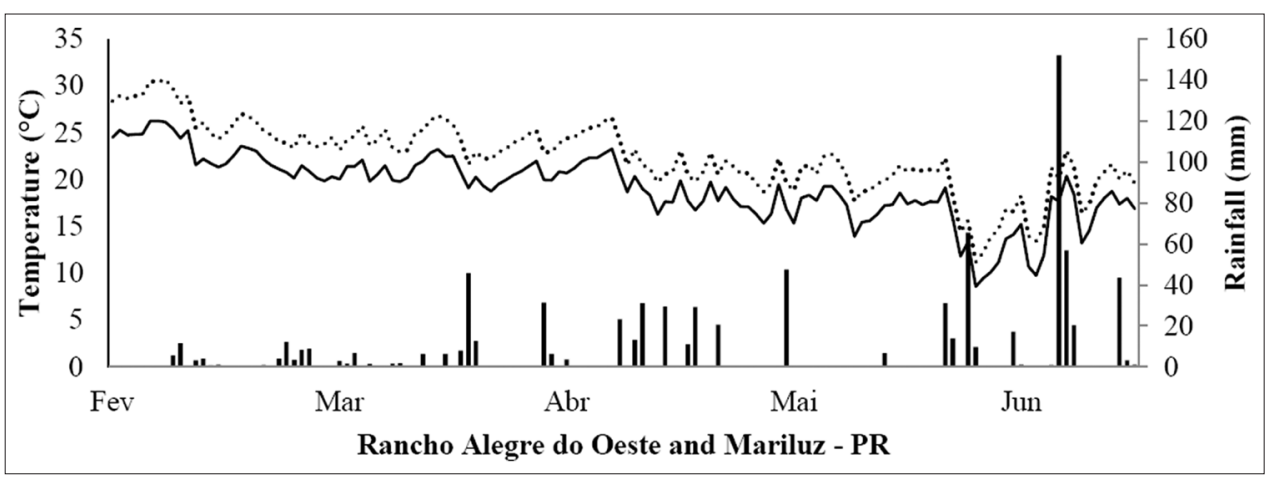

Fig 1. Climatic daily data of rainfall (solid bat), maximum (dotted line) and minimum (solid line) temperature during the experimental time.

\begin{tabular}{|c|c|c|c|c|c|}
\hline Treatments & $\begin{array}{c}\text { Rates } \\
\left(\text { kg ha-1) }^{-1}\right.\end{array}$ & $\begin{array}{l}\text { Phosphorus } \\
\qquad\left(\mathrm{g} \mathrm{ha}^{-1}\right)\end{array}$ & $\begin{array}{c}\text { Calcium } \\
\left(g^{h} a^{-1}\right)\end{array}$ & $\begin{array}{l}\text { Potassium } \\
\left(\mathrm{g} \mathrm{ha}^{-1}\right)\end{array}$ & $\begin{array}{l}\text { Boron } \\
\left(g \text { ha }^{-1}\right)\end{array}$ \\
\hline 1 & 0 & 0 & 0 & 0 & 0 \\
\hline 2 & 0.5 & 120 & 40 & 20 & 12.5 \\
\hline 3 & 1.0 & 240 & 80 & 40 & 25.0 \\
\hline 4 & 1.5 & 360 & 120 & 60 & 37.5 \\
\hline 5 & 2.0 & 480 & 160 & 80 & 50.0 \\
\hline 6 & 2.5 & 600 & 200 & 100 & 62.5 \\
\hline
\end{tabular}

$8 \% \mathrm{Ca}, 2.5 \% \mathrm{~B}$ and $4 \% \mathrm{~K}$, applied at 0, 0.50, 1.0, 1.5, 2.0 and $2.5 \mathrm{~kg} \mathrm{ha}^{-1}$, respectively) at the R3 stage (onset of pod formation) (Embrapa, 2014). The rates of each nutrient applied per hectare are shown in Table 2.

\section{Experimental area management}

The soybean genotype used was NA5909 RG. It was sown at 40 seeds $\mathrm{m}^{-2}$, a large quantity, becauseof the late sowing period and because soybeans take less time to bloom when sown at this time. All seeds were treated with pyraclostrobin + methyl thiophanate + fipronil at a dosage of $250 \mathrm{~mL}$ for each $100 \mathrm{~kg}$ of seeds.

For basic fertilization, $200 \mathrm{~kg} \mathrm{ha}^{-1}$ of a mineral fertilizer with 2-20-18 formulation was applied by broadcasting (top-dressed), along with $60 \mathrm{~kg} \mathrm{ha}^{-1}$ of ammonium sulfate $(21 \%$ of $\mathrm{N})$. The remaining agricultural treatments were performed according to Embrapa (2013)

\section{Variable responses}

The following traits were evaluated in the R6 soybean stage: final stand (FS), height of plants (HP), height of insertion of the first pod (HIFP), number of branches (NB) and number of pods per plant (NPP). After the harvest, the thousand mass seed (TMS) and yield (YIE) were also measured.

The FS was obtained by averaging the number of plants counted in two lines per plot. The HP and HIFP were obtained with a millimeter ruler by measuring five plants per plot, and the results were expressed in centimeters. NPP and $\mathrm{NB}$ were determined by counting these items in five plants randomly chosen per plot. The YIE was determined by harvesting the useful area per plot $\left(7.2 \mathrm{~m}^{2}\right)$ and extrapolating the results into kilograms per hectare. The TMS was determined by weighing eight subsamples of 100 seeds per plot on a semi-analytical balance. The average values obtained were multiplied by ten and expressed in $\mathrm{g}$ (Brasil, 2009).

The physiological quality of the seeds was determined by the standard germination (SG), first germination (FG), accelerated aging test (AA), modified cold (MC), emergency speed index (MSI) and electric conductivity (EC). SG was performed with four subsamples of 50 seeds for each plot. The seeds were placed between three sheets of paper towels moistened with distilled water, with an amount of water equivalent to 2.5 times the mass of the dry paper being used. Rolls were prepared, which were taken to the Mangelsdorf germinator, which was regulated to maintain a constant temperature of $25^{\circ} \mathrm{C}$, where the rolls were kept for a period of eight days. The results were expressed as the percentage of normal seedlings (Brasil, 2009). FG measured together with the SG, was used to compute the percentage of normal seedlings obtained on the fifth day after the onset of SG. (Brasil, 2009).

EC was performed using four subsamples of 50 seeds for each plot. Initially, the seeds were placed in plastic cups $(200 \mathrm{~mL})$ and weighed to an accuracy of $0.01 \mathrm{~g}$. After the seeds had been weighed, $75 \mathrm{~mL}$ deionized water was added 
to the plastic cups. These cups were kept in a germination chamber (BOD) at $25^{\circ} \mathrm{C}$ for 24 hours (Loeffler et al., 1988). Afterwards, the electrical conductivity was measured in the solution using a digital microprocessor conductivity meter (model TEC-4MP), and the result was expressed $\mu \mathrm{S} \mathrm{cm}^{-1} \mathrm{~g}^{-1}$ (Vieira and Krzyzanowski, 1999).

MC was performed using germination paper as the substrate, with water applied at a ratio 2.5 times the dry weight of the paper, the same as with SG, and with four replicates of 50 seeds evenly distributed throughout the substrate, which was used to form the rolls. The rolls were placed in plastic bags and then sealed with crepe tape. These were kept in a pre-adjusted BOD chamber at $10^{\circ} \mathrm{C}$, where they remained for five days. Then, the bags were opened, and the rolls were placed in a Mangelsdorf-type germinator set at $25^{\circ} \mathrm{C}$ for five days. The results were expressed as the percentage of normal seedlings.

AAT was conducted with four subsamples of 50 seeds per plot, which were arranged on a stainless-steel screen inserted in plastic boxes (gerboxes) containing $40 \mathrm{~mL}$ of deionized water. Subsequently, the boxes were taken to a germinating chamber (BOD) at $42^{\circ} \mathrm{C}$ for 48 hours. After this period, the seeds were submitted to the germination test, as previously described. The evaluation was performed on the fifth day after the start of the test, with the seedlings considered normal being counted (Marcos Filho, 1999). The results were expressed as a percentage.

The MSI was performed using four subsamples per plot. The seeds were sown $3 \mathrm{~cm}$ deep in plastic boxes containing moist washed sand. The test was conducted in a drying oven with no light and temperature control. The normal seedlings that had emerged were counted until the emergency stabilization. MSI was calculated according to Vieira \& Krzyzanowski (1999).

For determination of their nutritional contents, the seeds were washed with deionized water and then placed in a drying oven with forced air circulation at $65^{\circ} \mathrm{C}$ until reaching a constant mass. After this process, the samples were milled with a Wiley-type mill. To measure nitrogen content (N), the Kjeldahl method (Silva, 2009) was used, based on distillation-titration. An analytical balance was used to weigh samples $(0.100 \mathrm{~g})$ previously ground in $90 \mathrm{~mL}$ digestion tubes. The reagents used in the digestion consisted of a catalytic mixture composed of potassium sulfate $\left(\mathrm{K}_{2} \mathrm{SO}_{4}\right)$ and copper sulfate $\left(\mathrm{CuSO}_{4}\right)$ 10:1, added directly to samples, as well as concentrated sulfuric acid $\left(\mathrm{H}_{2} \mathrm{SO}_{4}\right)$ and hydrogen peroxide $\left(\mathrm{H}_{2} \mathrm{O}_{2}\right)$. For the distillationtitration, $10 \mathrm{~mol} \mathrm{~L}^{-1}$ sodium hydroxide $(\mathrm{NaOH}), 10 \mathrm{~g} \mathrm{~L}^{-1}$ boric acid $\left(\mathrm{H}_{3} \mathrm{BO}_{3}\right)$, and $0.02 \mathrm{~mol} \mathrm{~L}^{-1}$ sulfuric acid $\left(\mathrm{H}_{2} \mathrm{SO}_{4}\right)$ were used.
For determination of the phosphorus $(\mathrm{P})$, potassium $(\mathrm{K})$, calcium $(\mathrm{Ca})$, magnesium $(\mathrm{Mg})$, sulfur $(\mathrm{S})$, Zinc $(\mathrm{Zn})$, manganese $(\mathrm{Mn})$ and boron $(\mathrm{B})$, the samples were weighed $(0.250 \mathrm{~g})$, added to Teflon tubes in which $6 \mathrm{~mL}$ of $\mathrm{HNO}_{3}$ was added, and allowed to stand for $30 \mathrm{~min}$. Then, the samples were digested on a wet basis in a microwave oven at a temperature of $230{ }^{\circ} \mathrm{C}$ and 25 bar pressure. After digestion, the samples were diluted and prepared for analysis by the inductively coupled plasma atomic emission spectrometry (ICP-OES) technique. This method is based on the principles for analysis of the dissolved metals in the solution (acid extraction) (Giné-Rosias, 1998).

\section{Statistical analysis}

The data from each site were submitted to the basic assumptions for the analysis of variance (where the additive mathematical model and the errors follow a normal distribution, are independently distributed with azero mean, and present a common variance) by the Shapiro-Wilk tests $(p<0.01)$ (normal distribution), and by Levene's test $(p<0.01)$.

Afterward, the data were submitted to variance analysis, and the ratio between the means squaredfor each site were compared by the Hartley test (Ramalho et al., 2000) for all traits. When the mean square ratio was lower than $7: 1$, the data were analyzed by joint analysis (Zimmerman, 2014) using SAS software 9.4.

The averages of each site were conclusive according to the $F$ test $(p<0.05)$. For the effect of the rates, these averages were significant when submitted to regression analysis ( $p$ $<0.05$ ). When the interaction between sites and rates was significant, the same analyses as previously described were used for the rates.

\section{RESULTS AND DISCUSSION}

\section{Yield components}

The joint variance analysis showed significance $(\mathrm{p}<0.05)$ between sites for the traits FS, HP, NPP, TMS and YIE (Table 3).

For rates, the traits NPP, TMS and YIE were significant. NVP and PROD showed significant interactions between sites and rates. Partitioning was performed to obtain the best regression model for each site. However, even when an interaction was not significant in the F-test, Partitioning was performed to verify the noted significant differences. Importantly, for most traits evaluated, the coefficients of variation were low, indicating good precision of the experiment.

The traits FS, HP, HIPF and NB did not present any significant differences. These results differ from those of 
Kappes et al. (2008), who after applying similar products to soybean plants, verified an increase in plant height. The TMS showed significant differences among the rates; however, the regression deviation, which measures the quality of the regression, was also significant, and adjustments to other models are necessary to better explain this variation.

NPP and YIE were significant in Mariluz, although the regression deviation was also significant; therefore, the need exists to fit other models for the explanation of the data variation. In Rancho Alegre d'Oeste, the NPP increased linearly according to the rates. Each kilogram of product applied increased the pods per plant by two with $76 \%$ certainty. The YIE was adjusted using a quadratic model in which the highest YIE was $1,864 \mathrm{~kg} \mathrm{ha}^{-1}$ with the application of $1.27 \mathrm{~kg} \mathrm{ha}^{-1}$ of product, and $87 \%$ of the results found are explained by this equation (Fig. 2).

Marin (2012) applied phosphate and has verified a significant effect only for number of seeds per plant and thousand grain mass, without differences for the stand of plants, number of pods per plant and yield. Pelá et al. (2009) tested different sources of $\mathrm{P}$ foliar applications in a greenhouse for a bean crop and verified yield increases for all sources when compared with a control. Rezende et al. (2005), using the same mode of application in the soybean crop, found a significant increase of $16 \%$ in yield when the commercial product $(30 \% \mathrm{P})$ was applied in the V5 stage. Other evaluated traits, such as the nutrient content in the leaves, lodging, and height of plants, did not present significant differences.

\section{Physiological seed quality}

The joint variance analysis to verify the physiological quality of the seeds revealed a significant effect $(p<0.05)$ of site for the traits SG, FG, MC, AA and EC (Table 4).

Only MSI showed a significant effect for the rates tested. However, only AA showed significance for the interaction between sites and rates. Even when the interaction was not significant by the F-test, the partitioning of rates and site factors was performed to verify possible significant differences.

Although a significant interaction was observed among sites and rates for MC, the variations of the results found in Mariluz-PR (Fig 3A) are due to environmental variation, whereas in Rancho Alegre d'Oeste other models that better explain this variation must be applied.

A linear model was adjusted when analyzing the MSI, with a positive angular coefficient being observed only for Mariluz-PR, and in Rancho Alegre the variation in the data occurred at random (Fig 3B), whereas 65\% of the variation of this result was explained by the linear adjustment in Mariluz.

Dan et al. (2010) cite the importance of fast emergence to the establishment of a stand in field conditions, and MSI is an important index that is directly correlated with high plant development, especially under conditions of stress. Seeds with lower emergence speed take a longer time to germinate and are more susceptible to attack by soil pathogens (Goulart, 2004).

Table 3: Averages of final stand (FS), height of plants (HP), height of insertion of the first pod (HIFP), number of pods (NP), number branches (NB), thousand mass seed (TMS) and yield (YIE)

\begin{tabular}{|c|c|c|c|c|c|c|c|}
\hline & $\begin{array}{c}\text { FS } \\
--\end{array}$ & $\begin{array}{l}\text { HP } \\
\mathrm{cm}\end{array}$ & $\begin{array}{c}\text { HIFP } \\
--\end{array}$ & $\begin{array}{c}\text { NP } \\
--\end{array}$ & $\begin{array}{c}\text { NB } \\
--\end{array}$ & $\begin{array}{c}\text { TMS } \\
\mathbf{g}\end{array}$ & $\begin{array}{c}\text { YIE } \\
\mathrm{kg} \mathrm{ha}^{-1}\end{array}$ \\
\hline Mariluz & $11.4^{\mathrm{b}}$ & $40.7^{a}$ & $7.7^{\mathrm{a}}$ & $3.2^{\mathrm{a}}$ & $40.5^{a}$ & $156.2^{\mathrm{b}}$ & $2390^{a}$ \\
\hline Rancho Alegre d'Oeste & $12.4^{\mathrm{a}}$ & $30.4^{b}$ & $7.9^{\mathrm{a}}$ & $2.9^{b}$ & $20.1^{b}$ & $169.7^{a}$ & $1807^{b}$ \\
\hline
\end{tabular}

Averages followed by the same letter in the column do not differ from each other at $5 \%$ significance by $\mathrm{F}$ test

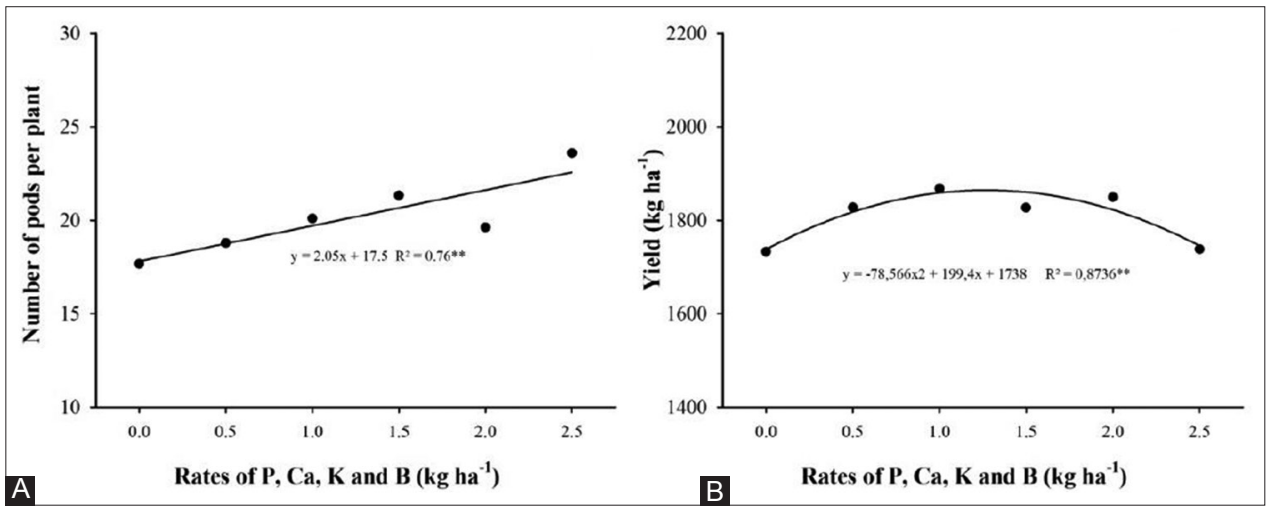

Fig 2. A) Number of pods per plant and B) soybean yield, obtained after foliar application of $P, C a, K$ and B in Rancho Alegre d'Oeste, Paraná, Brazil 
Notably, foliar application of a product cannot be inferred to increase the soybean seed physiological quality because of a positive result in the MSI since more than one test with a positive and significant result is necessary (Marcos Filho 2005). Marin (2012), also concluded that viability and vigor, as well as yield, were only significant at a rate $200 \%$ higher than recommended.

\section{Macro and micronutrient seed content}

The joint variance analysis of the nutrients seed contents revealed a significant effect of site $(\mathrm{p}<0.05)$ for all nutrients other than $\mathrm{N}, \mathrm{K}$ and $\mathrm{Cu}$ (Table 5).

Regarding rates applied, the nutrients P, K, Mg, S, Zn and B presented significant responses. Even when the interactions among factors were not significant in the $F$ test, partitioning was performed to verify possible significant differences.

For the $\mathrm{P}$, the quadratic regression equation model provided the explanation for the variation of the results in both

Table 4: Standard germination (SG), first germination (FG), modified cold (MC), accelerated aging test (AA), emergence speed index (MSI) and electrical conductivity (EC)

\begin{tabular}{lcccccc} 
& $\begin{array}{c}\text { SG } \\
\%\end{array}$ & $\begin{array}{c}\text { FG } \\
\%\end{array}$ & $\begin{array}{c}\text { MC } \\
\%\end{array}$ & $\begin{array}{c}\text { AA } \\
\%\end{array}$ & $\begin{array}{c}\text { MSI } \\
--\end{array}$ & $\begin{array}{c}\text { EC } \\
\mu S S ~ \text { cm}^{-1}\end{array}$ \\
\hline Mariluz & $96.2^{\mathrm{b}}$ & $96.2^{\mathrm{b}}$ & $96.2^{\mathrm{a}}$ & $91.3^{\mathrm{b}}$ & $33.6^{\mathrm{a}}$ & $27.7^{\mathrm{b}}$ \\
Rancho & $98.7^{\mathrm{a}}$ & $98.4^{\mathrm{a}}$ & $95.3^{\mathrm{b}}$ & $95.8^{\mathrm{a}}$ & $33.1^{\mathrm{a}}$ & $24.3^{\mathrm{a}}$ \\
$\begin{array}{l}\text { Alegre } \\
\text { d'Oeste }\end{array}$ & & & & & & \\
\hline
\end{tabular}

Averages followed by the same letter in the same column do not differ from each other at $5 \%$ significance by the $\mathrm{F}$ test places, providing evidence that the commercial product increases the levels of phosphorus in the seed in different environments. The maximum concentration of $\mathrm{P}$ was $5.50 \mathrm{~g} \mathrm{~kg}^{-1}$, which was obtained at an application rate of $1.13 \mathrm{~kg} \mathrm{ha}^{-1}$ (Fig 4A).

Few studies exist in the literature regarding foliar $\mathrm{P}$ application for soybean. Sfredo et al. (1997), in their work with $\mathrm{P}$, cobalt and molybdenum, concluded that seeds with high phosphorus content may have higher initial development, possibly influencing yield, especially under conditions of environmental stress. This may explain the results of Marin (2012), in which the yield obtained from plants that received twice the rate of $\mathrm{P}$ in soil fertilization were higher than the others. In addition, Marin (2012) also concluded that high rates of $\mathrm{P}$ contribute to the increase in the $\mathrm{P}, \mathrm{Fe}$ and $\mathrm{Zn}$ contents in the seed.

Trigo et al. (1997) found an increase in seedling dry matter, plant height, number of seeds per plant, thousand seed mass and yield after applications that yielded an increase in the P content in seeds. These authors also reported that the $\mathrm{P}$ content in the seed, especially under conditions of low availability of this nutrient in the soil, may be relevant to the initial establishment of the crop.

Teixeira (1994), in studies with bean seeds containing different concentrations of $\mathrm{P}$, observed that seeds containing a higher content of this nutrient were less

Table 5: Nitrogen (N), phosphorus (P), calcium (Ca), magnesium (Mg), sulfur (S), zinc (Zn), manganese (Mn), iron (Fe), copper (Cu) and boron (B) seed content after foliar fertilizer application in Mariluz and Rancho Alegre d'Oeste

\begin{tabular}{|c|c|c|c|c|c|c|c|c|c|c|c|}
\hline & $\mathbf{N}$ & $\mathbf{P}$ & $\mathrm{K}$ & $\begin{array}{l}\mathrm{Ca} \\
\mathrm{g} \mathrm{kg}^{-1}\end{array}$ & & 5 & $\mathrm{Zn}$ & Mn & $\begin{array}{c}\mathrm{Fe} \\
\mathrm{mg} \mathrm{kg}^{-1}\end{array}$ & $\mathrm{Cu}$ & B \\
\hline Mariluz & $58.2^{a}$ & $4.9^{a}$ & $16.1^{a}$ & $2.6^{a}$ & $3.0^{a}$ & $2.6^{a}$ & $28.8^{b}$ & $26.7^{b}$ & $87.0^{a}$ & $12.5^{a}$ & $25.9^{a}$ \\
\hline Rancho Alegre d'Oeste & $58.8^{a}$ & $4.1^{\mathrm{b}}$ & $16.2^{\mathrm{a}}$ & $1.9^{\mathrm{b}}$ & $2.8^{\mathrm{b}}$ & $1.6^{\mathrm{b}}$ & $36.8^{\mathrm{a}}$ & $38.4^{a}$ & $73.3^{b}$ & $12.5^{\mathrm{a}}$ & $24.9^{b}$ \\
\hline
\end{tabular}

Averages followed by the same letter in the same column do not differ from each other at $5 \%$ significance by $F$ test

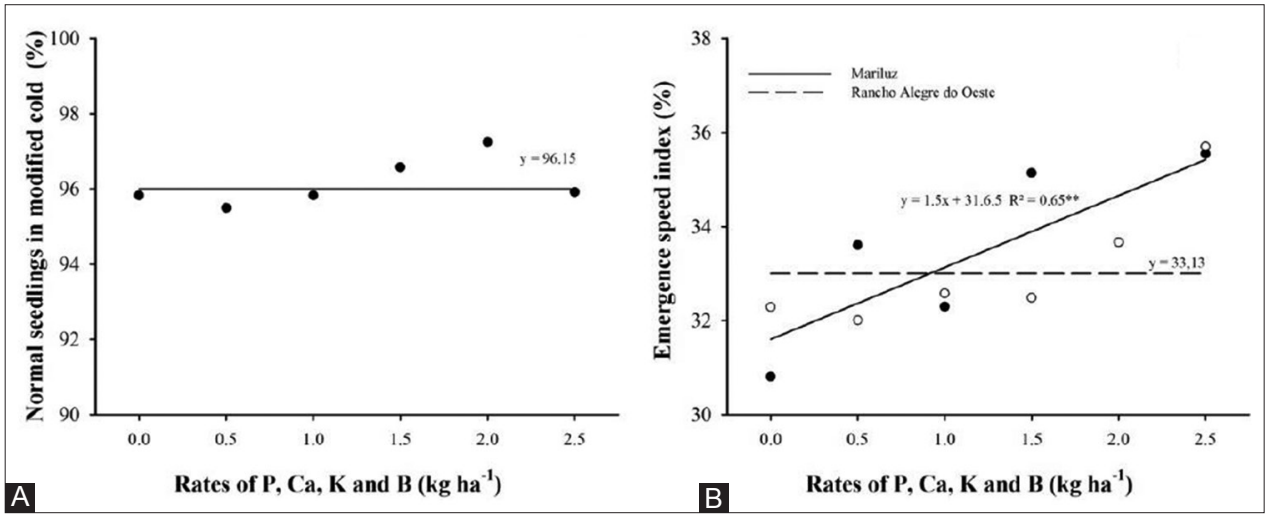

Fig 3. A) Percentage of normal seedlings in modified cold test and B) emergence speed index, obtained after foliar application of $\mathrm{P}$, Ca, $\mathrm{K}$ and Bin Mariluz and Rancho Alegre d'Oeste. 

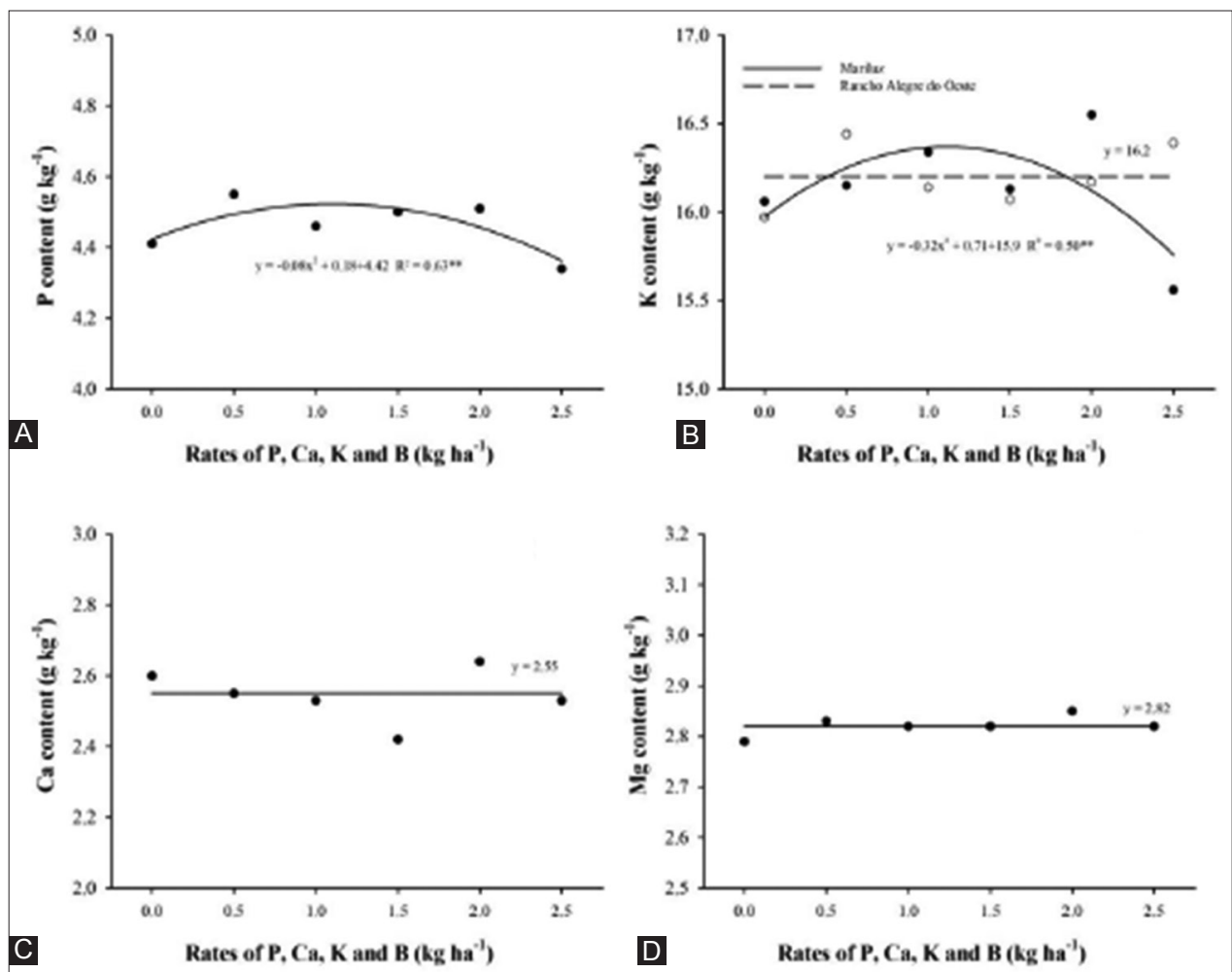

C
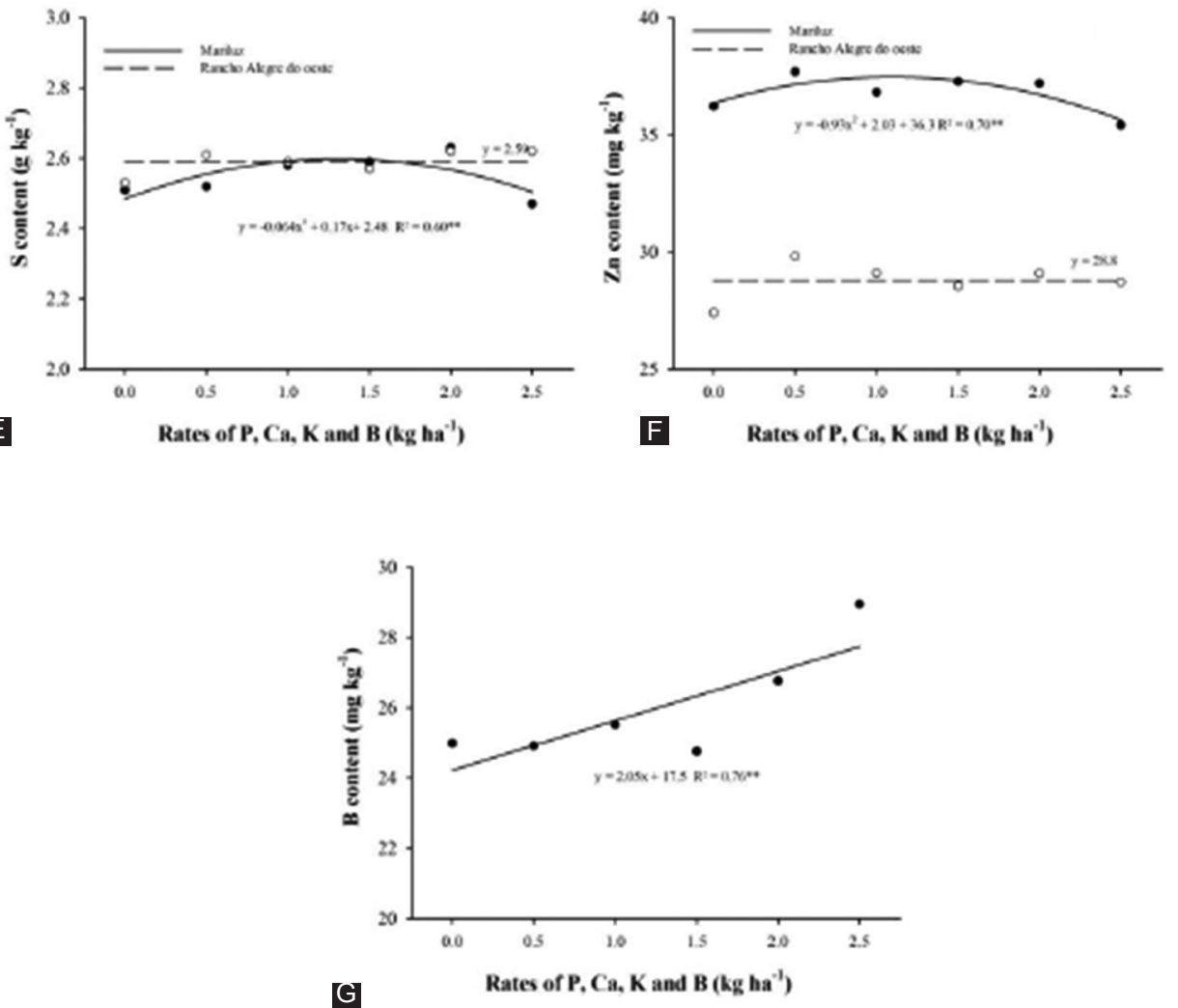

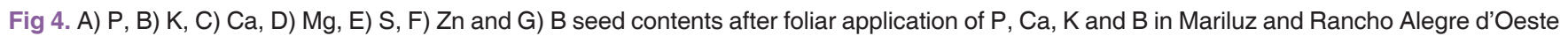

dependent on the phosphate fertilization in the soil. In addition, these seeds with higher levels of $\mathrm{P}$ produced more and heavier nodules, which reflected a higher biological N fixation, compared to seeds of low P content. 
Regarding K, a quadratic adjustment was observed in Mariluz, with maximum $\mathrm{K}$ content $\left(16.4 \mathrm{~g} \mathrm{~kg}^{-1}\right)$ obtained with the rate of $1.11 \mathrm{~kg} \mathrm{ha}^{-1}$ (Fig 4B). Importantly, the content of this nutrient in the soil is low (Embrapa, 2013); therefore, the foliar application functioned as a preventive fertilization according to Rosolem (2002). In Rancho Alegre d'Oeste, the variation in the data was random.

In Mariluz, for the $\mathrm{Ca}$ and $\mathrm{Mg}$ contents, no models were found to explain the agronomic variation in the results (Fig. 4C and 4D). A quadratic adjustment was found for $\mathrm{S}$ and $\mathrm{Zn}$ content (Fig 4E and 4F), however, with maximum concentrations of $2.59 \mathrm{~g} \mathrm{~kg}^{-1}$ and $37.41 \mathrm{mg} \mathrm{kg}^{-1}$, respectively, being obtained with applications of 1.33 and $1.09 \mathrm{~kg} \mathrm{ha}^{-}$ ${ }^{1}$ of product.

A linear regression equation model was the best for explaining the variation in the results in Mariluz for B (Fig 4G). The higher the applied rate of B, the higher the content of this element in the seed. On the other hand, in Rancho Alegre d'Oeste, other models were needed to better explain the variation in the results.

\section{CONCLUSION}

The foliar application of fertilizer containing $\mathrm{P}, \mathrm{Ca}, \mathrm{K}$ and $\mathrm{B}$ did not influence the HIPF, HP, NB and TMS. In Rancho Alegre d'Oeste, the NPP increased linearly with the application of foliar fertilizer, and therefore, the yield also increased. Even when the MSI increased in Mariluz-PR, the physiological quality of the soybean seed of cultivar NA 5909 RG was not significantly affected, although the seeds reached the quality necessary to be commercialized at both sites. Regarding the nutritional contents in the seeds, the foliar application of the fertilizer influenced the following nutrients positively: P (both sites), K, S, Zn and B (Mariluz-PR).

\section{Author contributions}

The first, second, third and fourth authors are graduate students (Master's and Doctoral candidates) and were responsible for delineating, installing and conducting the experiments at the two sites evaluated. In addition, all collections and analyses were performed by these authors, who worked in the field and in the laboratory. They were also responsible for drafting the manuscript in question. The sixth author contributed to the analyses and statistical interpretations and is one of the co-advisors for the research. The eighth author is a research guiding teacher, who jointly outlined the experiment with the fifth and seventh authors (also co-advisors), who are the professors responsible for the equipment used to perform the analyses. This research would not have been possible without the input of all authors because the experimental sites were far from our university

\section{REFERENCES}

Alvares, C. A., J. L. Stape, P. C. Sentelhas, J. L. M. Gonçalves and G. Sparovek. 2013. Köppen's climate classification map for Brazil. Meteorol. Z. 22: 711-728.

Arantes, R. P., T. N. Cury, F. D. P. Leão and V. A. M. Junior. 2009. Aplicação foliar de cálcio e boro a base de cloreto de cálcio e ácido bórico misturado no tanque para avaliação de rendimento da semente de soja. Nucleus. 6:117-122.

Bevilaqua, G. A. P., P. M. Silva Filho and J. C. Possenti. 2002. Aplicação foliar de cálcio e boro e componentes de rendimento e qualidade de sementes de soja. Ciênc. Rur. 32: 31-34.

Brasil. 2009. Regras Para Análise de Sementes. Ministério da Agricultura, Pecuária e Abastecimento. Secretaria de Defesa Agropecuária. Mapa/ACS, Brasília.

Burton, M. G., M. J. Lauer and M. B. McDonald. 2000. Calcium effects on soybean seed production, elemental concentration, and seed quality. Crop. Sci. 40: 476-482.

Conab. 2014. Companhia Nacional de Abastecimento. Séries Históricas. from: Available from: http://www.conab.gov.br. [Last accessed on 2019 Apr 01].

Corrêa, J. C., M. Mauad and C. A. Rosolem. 2004. Fósforo no solo e desenvolvimento de soja influenciados pela adubação fosfatada e cobertura vegetal. Pes. Agropec. Bras. 3: 1231-1237.

Dan, L. D. M., H. D. A. Dan, A. D. L. Barroso and A. L. Braccini. 2010. Qualidade fisiológica de sementes de soja tratadas com inseticidas sob efeito do armazenamento. Rev. Bras. Sem. 32: 131-139.

Embrapa. 2013. Tecnologias de Produção de Soja Região Central do Brasil. Embrapa-CNPSo, Londrina.

Embrapa. 2013. Sistema Brasileiro de Classificação de Solos. Embrapa-CNPS, Rio de Janeiro.

Esper Neto, M., M. R. Besen, C. F. Coneglian, E. A. Minato, R. S. Lima, T. T. Inoue and M. A. Batista. 2018. Teores de macro e micronutrientes no grão e produtividade de soja [Glycine max (L). Merr.] após aplicação de enxofre elementar foliar. Rev. Ci. Agrar. 41: 71-80.

Giné-Rosias, M. F. 1998. Espectrometria de Emissão Atômica com Plasma Acoplado Indutivamente. Piracicaba CPG-Cena-USP, Piracicaba.

Goulart, A. C. P. 2004. Fungos em Sementes de Soja: Detecção, Importância e Controle. Embrapa-Agropecuária Oeste, Dourados.

Kappes, C., A. L. Golo and M. A. C. Carvalho. 2008. Doses e épocas de aplicação foliar de boro nas características agronômicas e na qualidade de sementes de soja. Sci. Agrar. 9: 291-297.

Loeffler, T. M., D. M. Tekrony and D. B. Egli. 1988. The bulk conductivity test as an indicator of soybean seed quality. J. Seed. Sci. 12: 37-53.

Macedo, F. B., N. T. Teixeira, A. M. Lima, C. R. Bernardes, D. J. B. Freitas and R. F. Oliveira. 2002. Boro no plantio e Ca e B em adubação foliar na produção da soja. Rev. Ecossist. 27: 87-89.

Marcos, F. J. 1999. Teste de envelhecimento acelerado. In: F. C. Krzyzanowski, R. D. Vieira and J. B. França-Neto (Eds.), Vigor de Sementes: Conceitos e Testes. Abrates, Londrina, pp. 1-24.

Marcos, F. J. 2005. Fisiologia de Sementes de Plantas Cultivadas. Fealq, Piracicaba.

Marin, R. S. F. 2012. Fósforo na Qualidade de Sementes de Soja e Consequente Desempenho na Produção de Grãos. (Master Thesis), Universidade Federal de Pelotas, Pelotas.

Nelson, K. A., P. M. Peter and N. Manjula. 2005. Response of no-till 
soybean [Glycine $\max (\mathrm{L}$.$) Merr.] to timing of pre plant and foliar$ potassium applications in a claypan soil. Agron. J. 97: 832-838.

Pelá, A., M. S. Rodrigues, J. S. Santana and I. R. Teixeira. 2009. Fontes de fósforo para adubação foliar na cultura do feijoeiro. Sci. Agraria. 10: 313-318.

Peske, F. B., L. Baudet and S. T. Peske. 2009. Produtividade de plantas de soja provenientes de sementes tratadas com fósforo. Rev. Bras. Sem. 31: 95-101.

Ramalho, M. A. P. 2000. A experimentação em Genética e Melhoramento de Plantas. Edufla, Lavras.

Rezende, P. M., C. F. Gris, J. G. Carvalho, L. L. Gomes and L. Bottino. 2005. Adubação foliar épocas de aplicação de fósforo na cultura da soja. Ciênc. Agrotec. 29: 1105-1111.

Rosolem, C. A. 1982. Nutrição Mineral e Adubação de Soja. Potafós, Piracicaba.

Rosolem, C. A. and A. E. Boaretto. 1987. Adubação foliar. In: Simpósio Brasileiro de Adubação Foliar. Anais Campinas, Fundação Cargill.

Seidel, E. P. and W. L. Basso. 2012. Adubação foliar a base de cálcio e boro no cultivo da soja (Glycine max). Sci. Agra. Par. 11: 75-81.

Sfredo, G. J., C. M. Borkert, A. F. Lantmann, M. C. Meyer, J. M. G. Mandarino and M. C. N. Oliveira. 1997. Molibdênio e Cobalto na Cultura da Soja. Embrapa, Londrina.
Silva, F. C. 2009. Análise química de tecido vegetal. In: Manual de Análises Químicas de Solo, Plantas e Fertilizantes. $2^{\text {nd }}$ ed. Embrapa Informação Tecnológica, Brasília, pp. 193-204.

Souza, L. C. D., M. E. D. Sá, M. A. C. Carvalho and H. M. Simidu. 2008. Produtividade de quatro cultivares de soja em função da aplicação de fertilizante mineral foliar a base de cálcio e boro. Rev. Bio. Cienc. Terr. 8: 17-44.

Teixeira, M. G. 1994. Influência do Conteúdo de Fósforo da Semente na Nodulação do Feijoeiro (Phaseolus vulgaris L.). (PhD Thesis), Universidade Federal Rural do Rio de Janeiro, Itaguaí.

Trigo, L. F. N., T. Peske, M. F. Gastal, L. C. Vahl and M. F. O. Trigo. 1997. Efeito do conteúdo de fósforo na semente de soja sobre o rendimento da planta resultante. Rev. Bras. Sem. 19: 111-115.

Vieira, R. D. and F. C. Krzyzanowski. 1999. Teste de condutividade elétrica. In: F. C. Krzyzanowski, R. D. Vieira and J. B. França Neto (Ed.), Vigor de Sementes: Conceitos e Testes. Abrates, Londrina, pp. 1-26.

Vieira, R. F., R. A. Fontes and J. R. P. Carvalho. 1987. Desempenho de sementes de feijão colhidas de plantas não adubadas com macronutrientes e com micronutrientes. Rev. Ceres. 34: 162-179.

Zimmerman, F. J. P. 2014. Estatística Aplicada à Pesquisa Agrícola. Embrapa Arroz e Feijão, Santo Antônio de Goiás. 